\section{Journal of Anatolian Environmental and Animal Sciences \\ (Anadolu Çevre ve Hayvancılık Bilimleri Dergisi) \\ Doi: https://doi.org/10.35229/jaes.637591}

\title{
Karadeniz Türkiye Kıyıları Yağış Miktarlarının Uzun Dönemli Değişimi
}

\author{
Eren ERSOY ${ }^{1} \quad$ Ertuğrul AĞIRBAŞ ${ }^{2 *}$
}

\author{
${ }^{I}$ Trabzon Meydan Meteoroloji Müdürlüğ̈̈, Trabzon, Türkiye. \\ ${ }^{2}$ Recep Tayyip Erdoğan Üniversitesi Su Ürünleri Fakültesi, 53100, Rize, Türkiye. \\ (D): https://orcid.org/0000-0001-8968-1751, " *iD: https://orcid.org/0000-0001-7987-9668
}

\author{
Received date: 24.10 .2019 \\ Accepted date: 12.12 .2019 \\ Atıf yapmak için: Ersoy, E. \& Ağırbaş, E. (2019). Karadeniz Türkiye Kıyıları Yağış Miktarlarının Uzun Dönemli Değişimi. Anadolu Çev. ve Hay. Dergisi, 4(3), \\ 513-518. \\ How to cite: Ersoy, E. \& Ağırbaş, E. (2019). Long Term Variation of Precipitation along the Black Sea Coast of Turkey. Anatolian Env. and Anim. Sciences, \\ 4(3), 513-518.
}

Öz: Bu çalışmada ülkemiz Karadeniz kıyılarından seçilen ve bölgenin iklimsel özelliklerini temsil edeceği düşünülen 7 ayrı noktadaki meteoroloji gözlem istasyonlarından elde edilen geçmiş yıllara ait yağış verilerinin uzun dönemli (1970-2018) meteorolojik analizi yapılmıştır. Ayrıca çalışmada yağış miktarlarının global iklimsel salınım indeks verileri ile ilişkileri incelenmiştir. Analizler sonucunda istasyonlara düşen toplam yağı̧̧ miktarları $333 \mathrm{~mm}$ (Sinop, 1986) ile $3380 \mathrm{~mm}$ (Hopa, 2016) arasında değişim göstermiş istasyonlar arasında istatistiki açıdan önemli farklılıklar tespit edilmiştir. Yıllık ölçekte yağış miktarlarında 0,08-0,43 mm'lik istatistiki olarak anlamlı bir artış tespit edilmiştir. İklimsel salınım indisleri ile yapılan regresyon analizleri neticesinde en iyi ilişki Kuzey Atlantik Salınım İndisi (NAO Index) ve Arktik Salınım İndisi (AO Index) ile Batı Havzasına ait yağış miktarları arasında elde edilmiştir. Güney salınım indisi (SO Index) ile istatistiki açıdan herhangi bir ilişki tespit edilememiş ve yağış verilerinin değerlendirilmesinde bölge için bir gösterge olamayacağ sonucuna ulaşılmıştır.

\section{Long Term Variation of Precipitation along the Black Sea Coast of Turkey}

Abstract: In this study, the long-term (1970-2018) meteorological analysis of the rainfall data of the past years obtained from the meteorological observation stations at 7 different locations, which are selected from the Black Sea coasts and which are thought to represent the climatic characteristics of the region, were conducted. In addition, the relationship between the rainfall values and global climatic index data was examined. As a result of the analyses, the total rainfall per stations varied from $333 \mathrm{~mm}$ (Sinop, 1986) to $3380 \mathrm{~mm}$ (Hopa, 2016) with statistically differences. Annually, a statistically significant increase of $0.08-0.43 \mathrm{~mm}$ was observed in the amount of precipitation. As a result of regression analyses, the best correlation was found between North Atlantic Oscillation Index (NAO Index) and Arctic Oscillation Index (AO Index) and precipitation amounts of the Western Basin. No statistically significant relationship was found with the Southern Oscillation Index (SO), and it was concluded that SO Index wouldn't be an indicator for the region in the evaluation of precipitation data. 


\section{GİRIŞ}

Atmosferde bulunan su buharının yoğunlaşarak katı veya sıvı halde yeryüzüne düşmesi yağış olarak tanımlanır. Yağışlar su döngüsündeki değişkenliğin belli başlı kaynağıdır. Yağış miktarlarında oluşacak bu değişimler hidroloji ve su kaynakları için çok önemli sonuçlar doğurabilir. Meteorolojik parametrelerde (sıcaklık, yağış, buharlaşma vb.) meydana gelen değişimlerin sebeplerinin araştırılması mevcut su kaynaklarının planlanması ve yönetimi bakımından önem arz et etmektedir. Son yıllarda olası etkileri araştırılmaya başlanan iklim değişikliği göz önünde bulundurulduğunda bu araştırmaların önemi daha da artmaktadır. İklimsel ve hidrolojik olarak büyük öneme sahip olan bu değişkenlerin sebep olduğu çevresel, sosyal ve ekonomik etki dünya üzerindeki yaşam koşullarını doğrudan etkilemektedir. Bu bağlamda, son yıllarda yapılan çalışmalar ile birlikte hidrometeorolojik değişkenler üzerinde büyük bir etkisi olan küresel atmosferik indeksler önemli bir araştırma konusu haline gelmiştir.

Türkiye konum itibariyle ekvatoral-tropik ve kuzey kutbu hava hareketlerinin arasında bulunduğu için meteorolojik olaylar genelde kararsız bir yapıda olma eğilimindedir. Türkiye yaz ve kış aylarında bahsi geçen hava hareketlerinin zaman zaman giriş yaptığı bir bölgedir. Kış aylarında kuzeyden gelen karasal ve denizsel karakterli kutupsal hava kütleleri Türkiye'ye giriş yaptığından, genel olarak hava soğuk, buharlaşma az ve yağışlar fazladır. Yaz aylarında ise güneyli tropik hava hareketlerinin etkisinden dolayı sıcaklık, nemlilik ve buharlaşma fazla, yağışlar ise azdir (Şen, 2003).

Günlük toplam yağış miktarı verileri, yağış şiddeti ve maksimum yağışlar açısından sel ve taşkın risk faktörleri konusunda önemli veri kaynakları oluşturur. Özellikle Doğu Karadeniz bölgesinde Hopa, Rize ve Pazar istasyonlarında sonbahar mevsiminde meydana gelen ve yağışın miktarı açısından periyodik bir düzene sahip bu alandaki sel ve taşkın olaylarının tespiti, günlük yağışlar ile yakından ilgilidir. $\mathrm{Bu}$ alanda, çok kısa zaman dilimlerinde görülen maksimum yağışlar, bazen bir aylık ortalama toplam yağıştan çok daha yüksek değerlere ulaşmakta ve bu tür yağışların neticesinde da çoğu kez taşkınlar gerçekleşmektedir. Ayrıca bu durum, Ege bölgesinde Muğla ve Marmaris istasyonlarında, kış mevsiminde, orta enlem siklonlarının (cephesel sistemlerin), Orta Akdeniz üzerinden kuzeydoğuya hareketi esnasında da sıkça görülmektedir. Sel olayı günlük çok şiddetli ve ani sağanak yağışlardan sonra oluşabildiği gibi günlerce devam eden yağışlardan sonra da, geciken taşkınlar şeklinde de etkili olmaktadır (Y1lmaz, 2008). Ekstrem hava olayları ile bağdaştırılan sel ve taşkın olaylarının önceden tahmin edilebilmesi can ve mal kayıplarını önemli ölçüde azaltacaktır. Türkiye'de ekstrem hava olayları toplamında 1960 ve 2000'li yıllarda önemli derecede artışlar olmuştur. $\mathrm{Bu}$ durumun ortaya çıkmasında ortalama sıcaklık sapması ile doğru orantılı olduğu gözlenmiştir (Şensoy vd., 2008).
Akdeniz, Karasal İç Anadolu ve Karasal Akdeniz Bölgeleri, kış mevsiminde görülen yağışlarda düşüş gösteren başlıca bölgelerdir. Sonbahar mevsimindeki yağışlar ise, Türkiye'nin önemli bir bölümünde artmaktadır. Türkiye'de yağış azlığına bağlı olarak son 20-30 yıldır yaşanan uzun süreli kuraklıklarda, küresel hava sistemlerindeki değişikliklerin ve sapmaların etkili olabileceği söylenebilir. Ayrıca Kuzey Atlantik Salınımının (NAO) pozitif devreleri Türkiye'deki kurak dönemlerle oldukça uyumludur. NAO'nun yanı sıra, yapılan bazı çalışmalara göre, El-Nino sisteminin kuvvetli olduğu yıllarda ya da bir yıl sonrasında da özellikle kış yağışlarında benzerliklerle karşılaşılmaktadır (Demir vd., 2008).

Hava sıcaklığı ile birlikte artan deniz yüzey sıcaklığı ve buna paralel olarak artan buharlaşma ekstrem olayları doğrudan etkilemektedir. Ekstrem yağışların sıklığı ve yoğunluğu bu şartlara bağlı olarak artış göstermektedir. Dünya genelinde yapılan birçok çalışma göstermektedir ki sıcaklık artışıyla birlikte her $1^{\circ} \mathrm{C}$ sıcaklık artışı için ekstrem yağışların \%7 artacağı ve gelecekte de yağış şiddetlerinin iklim değişikliğine bağlı olarak artış göstereceği tahmin edilmektedir (Seneviratne vd., 2012). Sahip olduğu nehir sistemi ile Yakın Doğu'daki birçok ülkeye su sağlayan Türkiye bu bağlamda jeopolitik ve tarihsel öneme sahiptir. Ayrıca Orta Doğu su rezervlerindeki herhangi doğal ya da insan kaynaklı azalmaya karşı oldukça hassas bir durumda bulunmaktadır (Cullen ve deMenocal, 2000). Küresel ısınma iklim değişikliğinin açık göstergesi olması yanında yağış ve firtına faaliyetlerinin bölgesel değişimleri de iklimde meydana gelen değişime sebep oluşturmaktadır. Hükümetler Arası İklim Değişikliği Paneli (Inter Govermantal Panel on Climate Change, IPCC 2001) son y1llarda s1caklıklarda tespit edilen $0.6 \pm 0.2^{\circ} \mathrm{C}$ bir artışın yağışlarda düzensizliğe ve yağış miktarlarında \%1'lik artışa neden olacağını öngörmektedir.

Son dönemlerde gerek dünya genelinde ve gerekse ülkemizde görülen ektstrem hava olayları ve bunlara bağlı olarak meydana gelen aşırı yağışların takip edilmesi ileriye dönük olarak sel ve taşkınlarla mücadelede karar vericilerin ihtiyaç duyduğu temel verilerin hazırlanması, planlama açısından kritik öneme sahiptir. $\mathrm{Bu}$ bağlamda mevcut çalışmada Karadeniz'in Türkiye kıyılarının yağış miktarlarının meteorolojik yönden analiz edilerek uzun dönemli değişimlerinin iklimsel salınım indisleri ile olan ilişkisinin ortaya konulması hedeflenmiştir.

\section{MATERYAL VE METOT}

Bu çalışmada, Karadeniz'in Türkiye kıyılarında yer alan sırasıyla batıdan doğuya doğru; Kumköy, Amasra, İnebolu, Sinop, Ordu, Giresun ve Hopa Meteoroloji istasyon müdürlüklerince ölçülmüş uzun dönemli (1970-2018) yağış veri setleri kullanılmıştır (Şekil 1). 


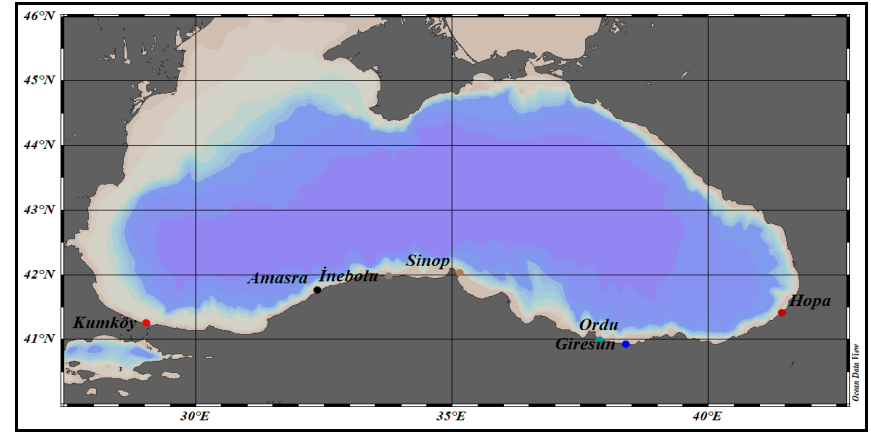

Şekil 1. Çalışma bölgesi ve meteorolojik ölçüm istasyonları.

Belirlenen istasyonlara ait meteorolojik veri setleri, Meteoroloji Genel Müdürlüğü tarafından sağlanan gözlem, sayısal hava tahmin modelleri, uydu, radar verileri ile diğer meteorolojik gözlem verileri kalite kontrol ve format dönüşümleri yapıldıktan sonra arşivlenerek, Meteorolojik Veri Bilgi Sunum ve Satış Sistemi (MEVBİS; http://mevbis.mgm.gov.tr) üzerinden temin edilmiştir.

Çalışma alanında bulunan Meteoroloji Gözlem İstasyonlarından alınan veriler çerçevesinde benzerlik analizi yapılmıştır (PRIMER 5) (Şekil 2). Bu analizler sonucunda Kumköy, İnebolu ve Amasra'dan elde edilen meteorolojik veriler kendi aralarında benzerlik gösterirken; Sinop, Ordu, Giresun ve Hopa'dan elde edilen meteorolojik veriler ise birbirleri arasında benzer özellik sergilemiştir. Yapılan benzerlik analizi neticesinde Karadeniz, iklimsel özelliklerine göre Batı ve Doğu Havzası olmak üzere iki farklı bölgeye ayrılmıştır.

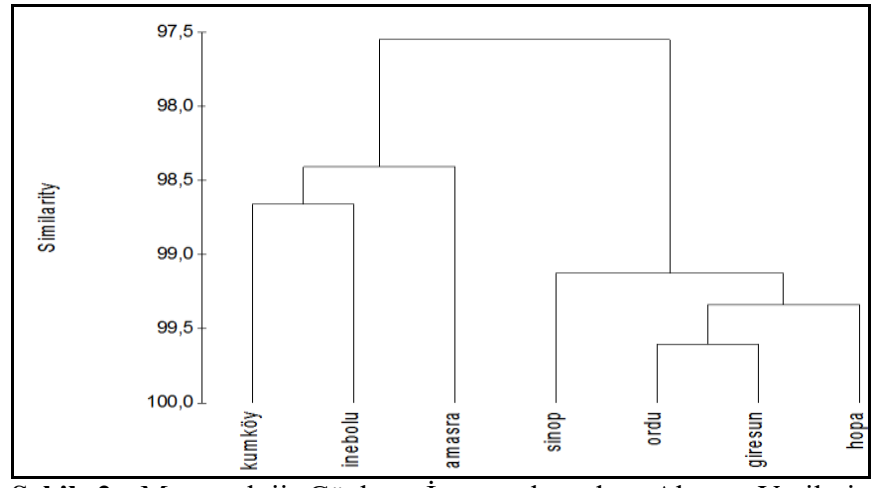

Şekil 2. Meteoroloji Gözlem İstasyonlarından Alınan Verilerin Benzerlik Analizi

İklimsel salınım indekslerinde; NAO (https://climatedataguide.ucar.edu/climate-data/hurrell-north-atlantic -oscillation-nao-index-station-based),

$\mathrm{AO}$

(https://www.daculaweather.com/4_ao_index.php) ve SO (https://www.ncdc.noaa.gov/teleconnections/enso/indicators/soi/) indislerine ait veriler ilgili web sayfalarından temin edilmiştir.

Grafikler ve istatiksel analizler SigmaPlot 11.0 programı kullanılarak gerçekleştirilmiştir. Veri setleri için trend analiz lineer regresyon ile gerçekleştirilmiş olup istatistiki açıdan önem derecesi ise "Pearson Korelasyon" katsayısı (r) ile "p" değeri ile gösterilmiştir (Sokal and Rohlf, 1969)

\section{BULGULAR}

Yağıs Miktarları: Karadeniz'in uzun dönemli yağış miktarları verisi analiz edildiğinde; son 49 yıl içerisinde yağış miktarında bir artış olduğu ancak bu artışın Doğu Havza hariç istatistik açıdan önemli olmadığı görülmüştür (Şekil 3). Regresyon analizleri yıllık bazda ortalama yağıŞ miktarlarında 0,08-0,43 $\mathrm{mm}$ arasında bir artış olduğu ve genel olarak Doğu Havza'ya düşen toplam yağış miktarının Batı Havzadan yüksek olduğunu göstermiştir. Ancak istasyonlara tek tek değerlendirildiğinde; yıllara göre yağış miktarlarında önemli bir artış trendi tespit edilmemiştir, ancak Giresun ve Hopa istasyonlarında önemli artışlar görülmüştür. Genel anlamda istasyonların ortalama yağış miktarları 1000 mm'nin altında kalırken Giresun ve Hopa istasyonlarında $1000 \mathrm{~mm}$ 'nin çok üstünde hatta 2000 mm'lere kadar ulaştığı tespit edilmiştir.

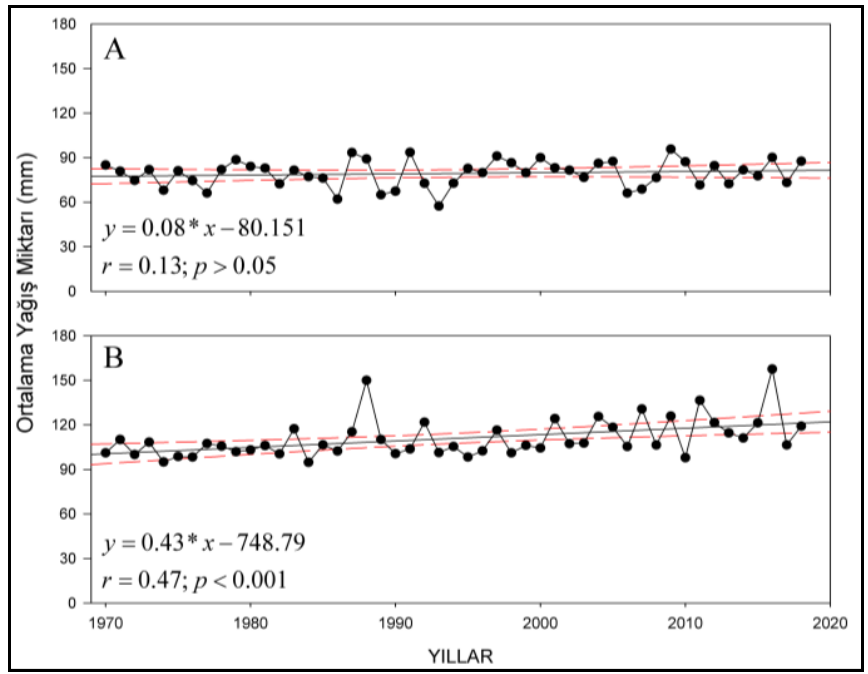

Şekil 3. Yıllara göre ortalama yağış miktarındaki değişim (A: Batı Havza, B: Doğu Havza).

İstasyonlara düşen toplam yağış miktarları $333 \mathrm{~mm}$ (Sinop, 1986) ile $3380 \mathrm{~mm}$ (Hopa, 2016) arasında değişim göstermiş (Şekil 4) ve yıllara göre istasyonlara düşen yağış miktarları arasında istatistiki açıdan önemli farklılıklar tespit edilmiştir (Kruskal-Wallis, $p<0,001$ ). Çalışma bölgesinde Hopa istasyonu (1685-3380 mm) diğer istasyonlara göre en fazla yağış alan istasyon olurken en az yağış alan istasyon Sinop (333-1009 mm) ve Kumköy (471-1231 mm) istasyonları olmuştur.

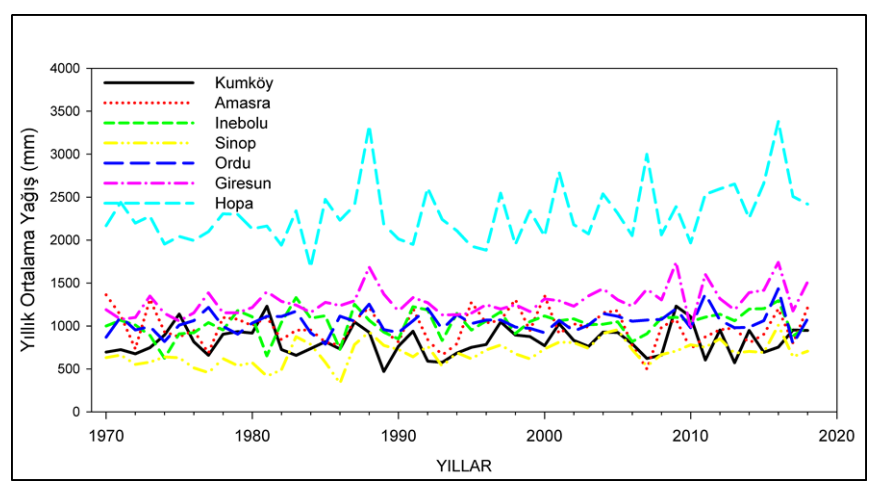

Şekil 4. Yıllara göre istasyonların toplam yağış miktarındaki değişim. 
Çalışmanın yürütüldüğü dönem içerisinde aylık yağış ortalamaları açısından bir karşılaştırma yapılldığında Doğu Havza'nın ait aylık yağış ortalamasının Batı Havza'dan yüksek olduğu tespit edilmiştir (Şekil 5) ve gözlemlenen bu farklılığın istatistiki olarak önemli olduğu görülmüștür ( $\mathrm{t}$ testi, $p<0,05)$. Aylık ölçekte Batı Havza'da yağış miktarları $44 \mathrm{~mm}$ (Temmuz)-130 mm (Aralık) arasında değişim gösterirken Doğu Havza'da ise $64 \mathrm{~mm}$ (Mayıs)-182 mm (Ekim) arasında değişmiştir. Yağışların en düşük olduğu aylar genel anlamda Nisan-Mayı-Haziran ayları olurken en yüksek yağışlar Eylül-Ekim-Kasım aylarında kaydedilmiştir.

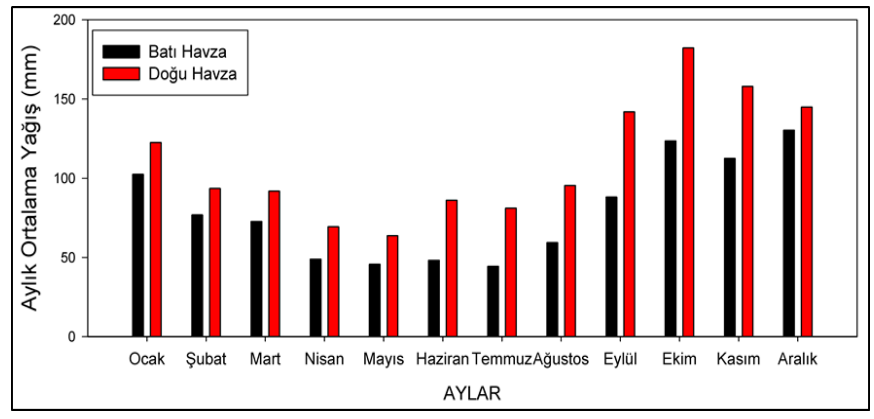

Şekil 5. Aylık ortalama yağış miktarındaki değişim.

Kuzey Atlantik Salınım Indisi (NAO Index): NAO indisi ile ortalama yağış miktarları değerlendirildiğinde, her iki havzada da negatif ve düzensiz ilişkiler tespit edilmiştir (Şekil 6). Batı Havzada 1980-1995 dönemi ve kısmen 2010 yılından sonra bir paralellik sözkonusu iken diğer dönemlerde ise negatif bir ilişki sözkonusudur. Doğu Havza ise 1985-1995 ve 2010-2018 dönemleri için benzer bir eğilim sergilerken ve diğer dönemlerde ise negatif bir ilişki sergilemiştir. Yapılan korealsyon analizlerinde Batı havza için NAO ile yağış miktarları arasında iststistik açıdan önemli ilişkiler (Spearman korelastonu $=-0,38 ; p<0,05$ ) tespit edilmiştir.

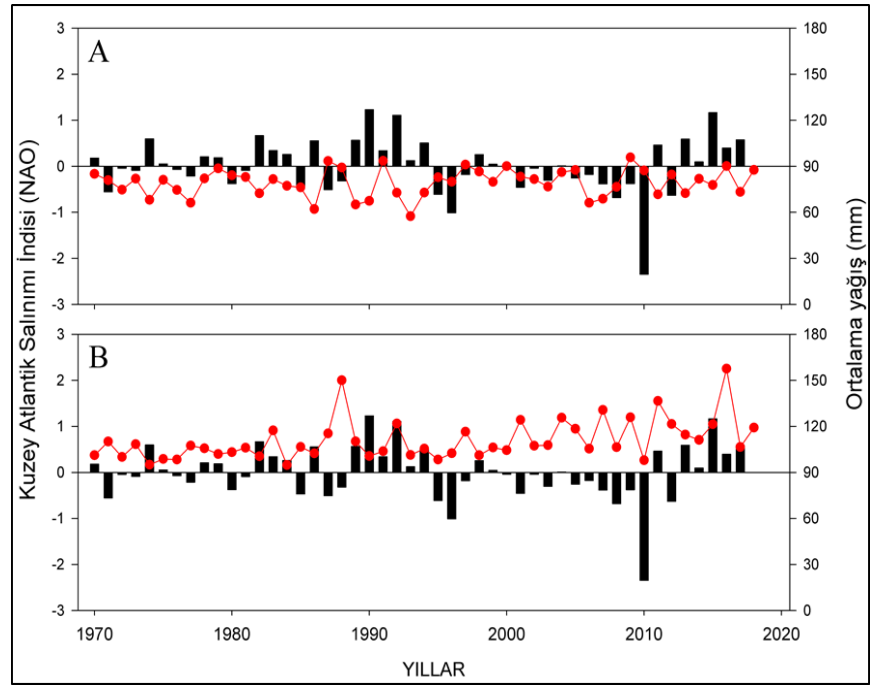

Şekil 6. Ortalama Yağış Miktarı ile Kuzey Atlantik Salınım İndisi arasındaki ilişki (A: Batı Havza, B:Doğu Havza, Bar grafiği: NAO indeksi, Çizgi grafiği: Ortalama yağış).
Güney Salınımı Índisi (SO Index): SO indisi ile her iki havza için ortalama yağış miktarları arasında düzensiz bir ilişki görülmektedir (Şekil 7). Spearman koralasyon analizi yağış mikatrı ile SO indisi arasında negatif ancak istatistiki açıdan önemli olmayan ilişkiler olduğunu ortaya koymuştur (Spearmen Korelasyonu, $p>0,05$ ).

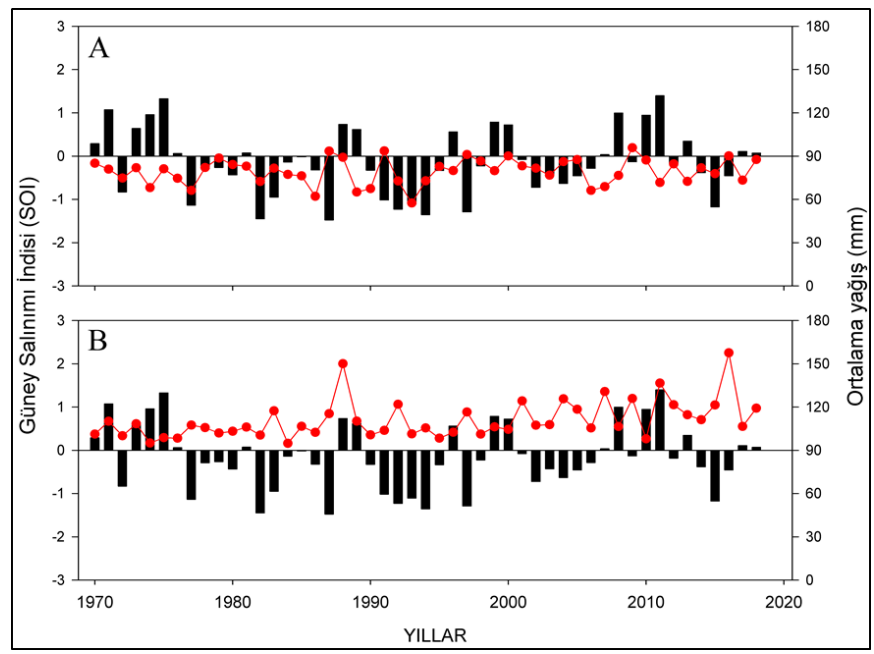

Şekil 7. Ortalama Yağış Miktarı ile Güney Salınım İndisi arasındaki ilişki (Bar grafiği: SO indeksi, Çizgi grafiği: Ortalama yağış).

Arktik Salınımı Índisi (AO Index): AO indisi ile ortalama yağıș miktarı ilişkilendirildiğinde, Batı Havzada 1990-2000'li yıllar arası hariç genel anlamda bir paralellik gösterdiği ve diğer dönemlerde ise negatif bir ilişki sergilediği tespit edilmiştir (Şekil 8). Doğu Havza ise 19901995 ve 2010-2018 dönemleri için benzer bir eğilim sergilerken ve diğer dönemlerde ise negatif bir ilişki sergilemiştir. Yapılan korealsyon analizlerinde Batı havza için AO ile yağış miktarları arasında iststistik açıdan önemli ilişkiler (Spearman korelasyonu= $-0,48 ; p<0,001$ ) tespit edilmiştir.

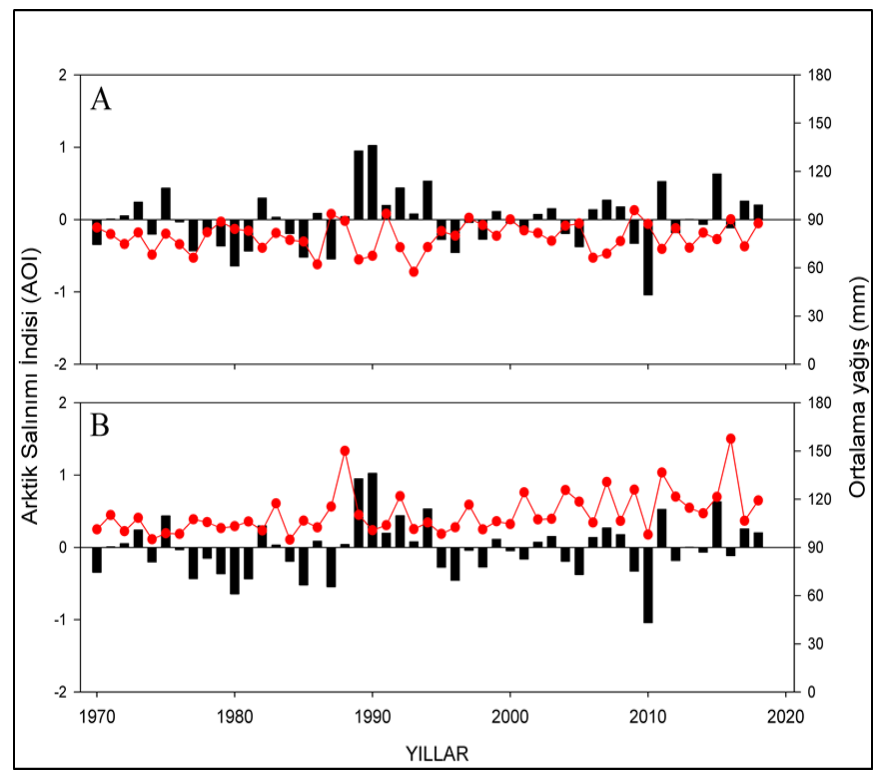

Şekil 8. Ortalama Yağış Miktarı ile Arktik Salınım İndisi arasındaki ilişki (Bar grafiği: AO indeksi, Çizgi grafiği: Ortalama yağış). 


\section{TARTIŞMA ve SONUÇ}

$\mathrm{Bu}$ çalışma ile Karadeniz Türkiye kıyılarında bulunan 7 adet meteoroloji gözlem istasyonundan alınan yağış veri setlerinde zaman içerisinde (1970-2018) bir değişim olup olmadığı araştırılmış ve elde edilen bulgular iklimsel salınım indisleri ile değerlendirilerek trend analizi uygulanmıştır.

Gerek küresel ve gerekse bölgesel ölçekte olsun iklim değişikliği beraberinde ekstrem hava olaylarının sıklığında, şiddetinde, bölgesel dağılışında, sürekliliğinde ve fenolojisinde değişiklikler olmasına neden olmaktadır. Trenberth vd. (2007), küresel yıllık yağıș ortalamalarında alansal ve zamansal olarak önemli değișimler olduğunu rapor etmiştir. 1901-2005 dönemi için yıllık yağış miktarı kuzey yarımkürenin orta ve yüksek enlemlerinde yaklaşık \%5-10 arasında artış gösterirken, Akdeniz Havzasının da yer aldığı subtropikal kuşağın büyük bir bölümünde yaklaşık \%30 dolaylarında azalımlar gözlenmiştir (Şekil 9). Türkiye'de ise özellikle Akdeniz yağış rejiminin etkili olduğu bölgelerde toplam yağış miktarlarında belirgin bir azalma eğilimi tahmin edilmektedir (Türkeş, 2012).

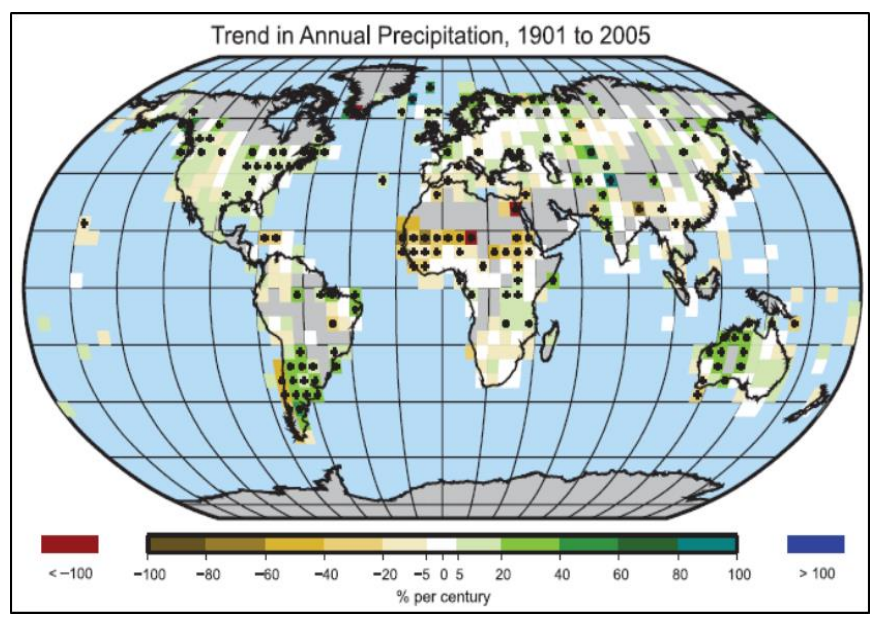

Şekil 9. 1901-2005 yılları arası kaydedilen yıllık yă̆ı̧̣ miktarlarındaki \% değişim (Trenberth vd., 2007).

Başka bir çalışmada ise 1979-2010 dönemi için küresel yağış miktarını ortalama 2,67 mm/gün olarak rapor edilmiştir (Şekil 10, URL-1). Yağış miktarları yıllar içerisinde gerek alansal ve gerekse zamansal ölçekte önemli değişimler göstermiştir. Alansal olarak en fazla yağışı ekvator ve çevresi alırken an az yağışı yüksek enlemler almıştır. Kuzey yarım küre bahsi geçen zaman dilimi içerisinde ortalamanın altında yağış alırken Türkiye'nin de içinde yer aldığı coğrafi konum $\left(36^{\circ}-42^{\circ}\right.$ Kuzey) ise ortalamaya yakın ve artan miktarda yağış almıştır.

Mevcut çalışmada ise 1970-2018 dönemi için yıllık ortalama yağış miktarlarında $0,08-0,43 \mathrm{~mm} / \mathrm{y} 1 \mathrm{l}$ arasında bir artış olup bu değer 1979-2010 yılı için rapor edilen ortalamanın $(2,67 \mathrm{~mm})$ çok altındadır. Ancak yapılan analizler son dönemlerde özellikle Doğu Havza’ya düşen toplam yağış miktarının Batı Havzadan yüksek olduğunu ortaya koymuştur. Havzaların yıllık toplam yağış miktarları değerlendirildiğinde; Batı Havza 689-1149 mm (ortalama $953 \mathrm{~mm}$ ) arasında değişen miktarda yağış alırken Doğu Havza 1137-1891 mm (ortalama $1330 \mathrm{~mm}$ ) arasında yağış almıştır.

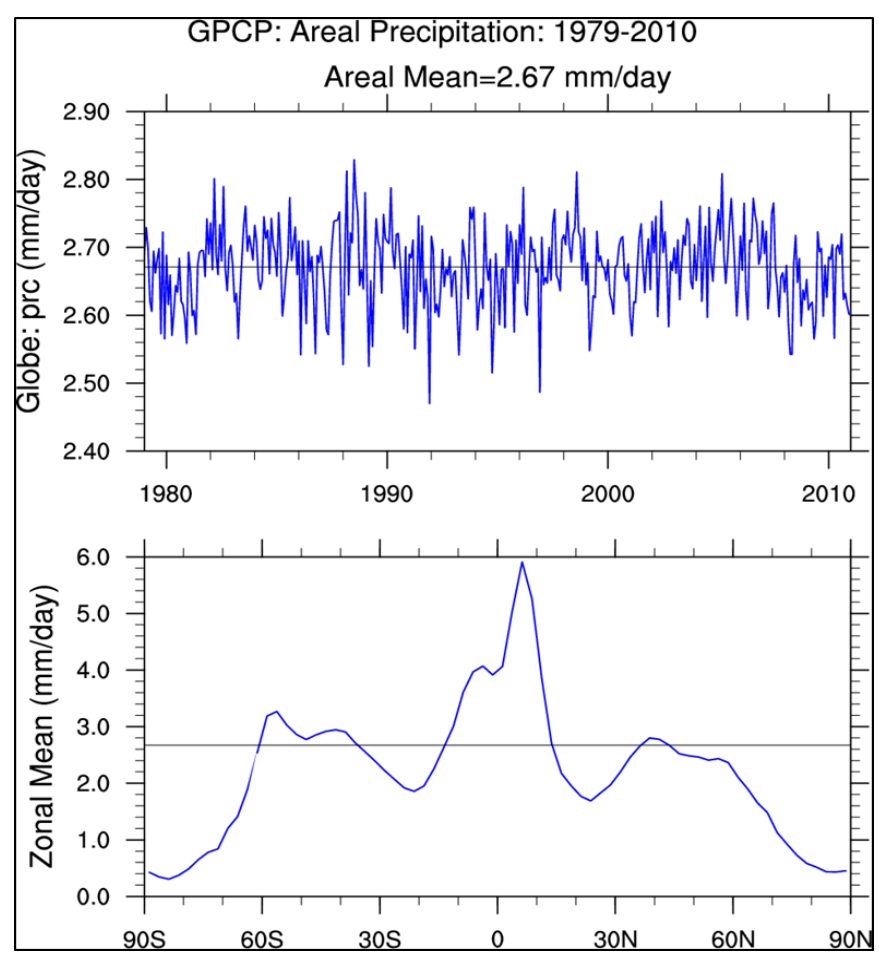

Şekil 10. 1979-2010 yılları arası kaydedilen günlük ortalama yağış miktarlarındaki alansal ve zamansal değişim (URL-1).

İklimsel salınım indisleri ile yapılan regresyon analizleri neticesinde en iyi ilişki NAO ve AO ile Batı Havzaya ait yağış miktarları arasında elde edilmiştir. Güney salınım indisi ile istatistiki açıdan herhangi bir ilişki tespit edilememiş ve yağış verilerinin değerlendirilmesinde bölge için bir gösterge olamayacağı sonucuna ulaşılmıştır. Rodo vd. (1997), güney salınımı ve NAO'nun İber Yarımadası'ndaki yağış rejimine etki ettiğini rapor etmişlerdir. Aynı araştırma grubu NAO'nun etkisinin yirminci yüzyıl boyunca sürdüğünü ancak güney salınımının ise özellikle yirminci yüzyılın ikinci yarısından sonra etkili olduğunu belirtmiştir. Türkiye'nin yağış miktarları açısından güney salınımının güney kesimlerinde değişimlere neden olduğunun ve bu bölgelerde kış mevsiminde yağışlarda azalmaların olacağını öngörülmektedir (Kadioglu vd.,1999). NAO, Türkiye iklimini özellikle yağışlı dönemler olan kış ve ilkbahar aylarında etkileyen bölgesel ölçekte bir salınım sistemdir. $\mathrm{Bu}$ anlamda Türkiye'de yağış/kuraklık olaylarını da etkileyen bir salınım olarak değerlendirilmelidir.

Türkeş vd., (2007) iklim değişikliğinin en belirgin ve göreli olarak daha kolay belirlenen sonuçlarından birisi olan küresel 1sınmanın Türkiye'de etkili olduğunu rapor etmiştir. Türkiye'de yıllık yağış miktarı ve yağış yoğunluğu miktarlarında özellikle Akdeniz ve Karadeniz yağış rejimi bölgelerinde kuvvetli azalmalar olacağı öngörülmektedir. Aksine mevcut çalışmada 1970-2018 dönemi içerisinde çalışma bölgesinde yağış miktarlarının ve özellikle de Doğu 
Havza'da önemli oranda arttığ 1 tespit edilmiştir. Bu artış 2000'li yıllardan sonra kendini daha da hissettirmiştir. IPCC tarafindan yayınlanan 5. rapora (AR5) göre Türkiye'nin de içinde bulunduğu bölgeyle ilgili olarak farklı senaryolar kullanılarak yapılan çalışmalarda yağış miktarları Türkiye'nin güney kısımlarında azalacaktır. Kuzey ve özellikle kuzeydoğu kısımlarında ise bir miktar artabilir (Şen, 2013). Rapor bulguları mevcut çalışmadan elde edilen sonuçlarla tutarlılık göstermektedir.

Sonuç olarak, bu çalışma sonucunda elde edilen bulgular çalışma bölgesinde önemli değişimlerin olduğunun bir göstergesidir. Ancak bunu kesin olarak söyleyebilmek için bölgenin çok daha yönlü (multi-disipliner) olarak çalışması gerekliliği öne çıkmaktadır. Aynı zamanda Karadeniz sahip olduğu kendine has dinamikleri ile sürekli izlenmesi gereken bir deniz özelliğindedir. Bütün dünyada özellikle son yıllarda iklim değişimini araştırılmasına yönelik çalışmalar giderek artmaktadır. Ülkemizde de bu çalışmaların artması hali hazırda var olan kaynakların ve ileride yapılacak projelerin belirlenmesinde etkili olacaktır. Gelecekte iklim sisteminde meydana gelebilecek olası değişikliklerin boyutları ve etkilerinin kestirilmesi, uyum çabaları, uyum araçları ve politikaların geliştirilmesi için iklim simülasyonlarının rolü ve önemi artmaktadır.

\section{KAYNAKLAR}

Cullen, H.M. \& deMenocal, P.B. (2000). North Atlantic influence on tigris-euphrates streamflow. International Journal of Climatology, 20, 853-869.

Demir, İ., Gönül, K., Mustafa, C. \& Sümer, U.M. (2008). "Türkiye'de maksimum, minimum ve ortalama hava sıcaklıkları ile yağış dizilerinde gözlenen değişiklikler ve eğilimler”, TMMBO İklim Değişimi Sempozyumu Bildiriler Kitabl, Ankara 13-14 Mart 2008, TMMOB Meteoroloji Mühendisleri Odas1, Ankara 2008, 69-84.

IPCC. (2001). Climate change 2001: Impacts, adaptation, and vulnerability. Contribution of Working Group II to the Third Assessment Report of the Intergovernmental Panel on Climate Change, Cambridge University Press, Cambridge, U.K.

Kadioglu, M., Tulunay, Y. \& Borhan, Y. (1999). Variability of Turkish precipitation compared to El Nino events. Geophysical Research Letters, 26(11), 1597-1600.

Rodo, X., Baert, E. \& Comin, F. (1997). Variations in seasonal rainfall in Southern Europe during the present century: relationships with the North Atlantic Oscillation and the El Niño-Southern Oscillation. Climate Dynamics, 13(4), 275-284.
Seneviratne, S. I., Nicholls, N., Easterling, D., Goodess, C. M., Kanae, S., Kossin, J. \& Zwiers, F.W. (2012). Changes in climate extremes and their impacts on the natural physical environment. In managing the risks of extreme events and disasters to advance climate change adaptation: Special report of the intergovernmental panel on climate change (Vol. 9781107025066, 109-230pp.). Cambridge University Press.

Sokal, R.R. \& Rohlf, F.J. (1969). Biometry. W. A. Freeman and Company. San Francisco, 340pp.

Şen, Z. (2003). Su bilimi ve yöntemleri. Su Vakfı Yayınları, 266, İstanbul.

Şen, Ö.L. (2013). IPCC'nin son raporu ışı̆̆ında Türkiye'de iklim değişikliği, olası etkileri ve çözüm önerileri, iklim değişikliğinde son gelişmeler: IPCC 2013 Raporu, Sabanc1 Üniversitesi İPM, İstanbul.

Şensoy, S., Demircan, M., Ulupınar, Y. \& Balta, İ. (2008). "Türkiye iklimi", Meteoroloji Genel Müdürlüğü.

Trenberth, K.E. \& Jones, P.D. (2007). Observations: surface and atmospheric climate change. In: climate change 2007: The physical science basis. contribution of working group $i$ to the fourth assessment report of the intergovernmental panel on climate change (Eds. S. Solomon, et al.), Cambridge University Press: Cambridge.

Türkeş, M., Koç, T. \& Sarış, F. (2007). Türkiye'nin yağış toplamı ve yoğunluğu dizilerindeki değişikliklerin ve eğilimlerin zamansal ve alansal çözümlemesi. A. ̈. TÜCAUM Coğrafi Bilimler Dergisi, 5(1), 5773.

Türkeş, M. (2012). Türkiye'de gözlenen ve öngörülen iklim değişikliği, kuraklık ve çölleşme, Ankara Üniversitesi Çevrebilimleri Dergisi, 4(2), 1-32.

Yılmaz, F. (2008). Antalya'nın günlük yağış özellikleri ve şiddetli yağışların doğal afetler üzerine etkisi. Sosyal Bilimler Dergisi, 10(1).

URL-1: https://climatedataguide.ucar.edu/climate-data/gpcpmonthly-global-precipitation-climatology-project.

*Corresponding author's:

Ertuğrul AĞIRBAŞ

Recep Tayyip Erdoğan Üniversitesi Su Ürünleri Fakültesi, 53100, Rize, Türkiye.

\E-mail: ertugrul.agirbas@erdogan.edu.tr

ORCID : https://orcid.org/0000-0001-7987-9668

Telefon : $+90(464) 2233385$

Faks : : $+90(464) 2234118$

GSM : +90 (553) 4779143 